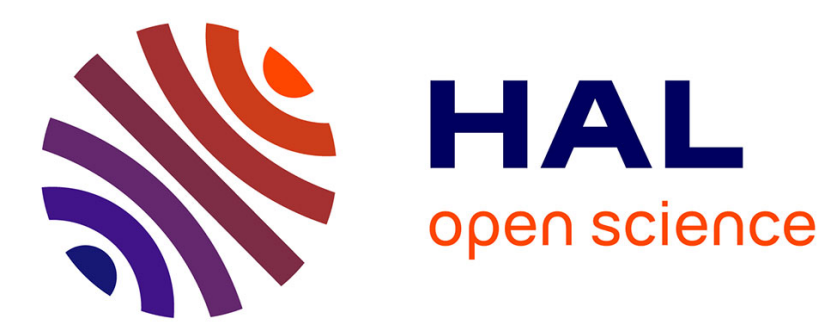

\title{
In vivo measurement of synthesis rate of multiple plasma proteins in humans
}

Abdul Jaleel, Vandana Nehra, Xuan-Mai Persson, Yves Y. Boirie, Maureen Bigelow, Sreekumaran Nair

\section{- To cite this version:}

Abdul Jaleel, Vandana Nehra, Xuan-Mai Persson, Yves Y. Boirie, Maureen Bigelow, et al.. In vivo measurement of synthesis rate of multiple plasma proteins in humans. AJP - Endocrinology and Metabolism, 2006, 291 (1), pp.E190-E197. 10.1152/ajpendo.00390.2005 . hal-02660634

\section{HAL Id: hal-02660634 \\ https://hal.inrae.fr/hal-02660634}

Submitted on 30 May 2020

HAL is a multi-disciplinary open access archive for the deposit and dissemination of scientific research documents, whether they are published or not. The documents may come from teaching and research institutions in France or abroad, or from public or private research centers.
L'archive ouverte pluridisciplinaire HAL, est destinée au dépôt et à la diffusion de documents scientifiques de niveau recherche, publiés ou non, émanant des établissements d'enseignement et de recherche français ou étrangers, des laboratoires publics ou privés. 


\section{Abdul Jaleel, Vandana Nehra, Xuan-Mai T. Persson, Yves Boirie, Maureen Bigelow and K. Sreekumaran Nair}

Am J Physiol Endocrinol Metab 291:190-197, 2006. First published Jan 31, 2006; doi:10.1152/ajpendo.00390.2005

You might find this additional information useful...

A corrigendum for this article has been published. It can be found at: http://ajpendo.physiology.org/cgi/content/full/292/1/E368

This article cites 36 articles, 16 of which you can access free at: http://ajpendo.physiology.org/cgi/content/full/291/1/E190\#BIBL

This article has been cited by 3 other HighWire hosted articles:

Differential effects of insulin deprivation and systemic insulin treatment on plasma protein synthesis in type 1 diabetic people

A. Jaleel, K. A. Klaus, D. M. Morse, H. Karakelides, L. E. Ward, B. A. Irving and K. S. Nair Am J Physiol Endocrinol Metab, October 1, 2009; 297 (4): E889-E897.

[Abstract] [Full Text] [PDF]

A comparison of $2 \mathrm{H} 2 \mathrm{O}$ and phenylalanine flooding dose to investigate muscle protein synthesis with acute exercise in rats

H. G. Gasier, S. E. Riechman, M. P. Wiggs, S. F. Previs and J. D. Fluckey

Am J Physiol Endocrinol Metab, July 1, 2009; 297 (1): E252-E259.

[Abstract] [Full Text] [PDF]

In vivo measurement of synthesis rate of individual skeletal muscle mitochondrial proteins A. Jaleel, K. R. Short, Y. W. Asmann, K. A. Klaus, D. M. Morse, G. C. Ford and K. S. Nair Am J Physiol Endocrinol Metab, November 1, 2008; 295 (5): E1255-E1268.

[Abstract] [Full Text] [PDF]

Updated information and services including high-resolution figures, can be found at:

http://ajpendo.physiology.org/cgi/content/full/291/1/E190

Additional material and information about AJP - Endocrinology and Metabolism can be found at: http://www.the-aps.org/publications/ajpendo

This information is current as of September 2, 2010 .

AJP - Endocrinology and Metabolism publishes results of original studies about endocrine and metabolic systems on any level of organization. It is published 12 times a year (monthly) by the American Physiological Society, 9650 Rockville Pike, Bethesda MD 20814-3991. Copyright @) 2006 by the American Physiological Society. ISSN: 0193-1849, ESSN: 1522-1555. Visit our website at http://www.the-aps.org/. 


\title{
In vivo measurement of synthesis rate of multiple plasma proteins in humans
}

\author{
Abdul Jaleel, ${ }^{1}$ Vandana Nehra, ${ }^{2}$ Xuan-Mai T. Persson, ${ }^{1}$ \\ Yves Boirie, ${ }^{1}$ Maureen Bigelow, ${ }^{1}$ and $\mathrm{K}$. Sreekumaran Nair ${ }^{1}$ \\ ${ }^{1}$ Division of Endocrinology, Diabetes, Metabolism, and Nutrition, and \\ ${ }^{2}$ Division of Gastroenterology and Hepatology, Mayo Clinic, Rochester, Minnesota
}

Submitted 19 August 2005; accepted in final form 30 January 2006

\begin{abstract}
Jaleel, Abdul, Vandana Nehra, Xuan-Mai T Persson, Yves Boirie, Maureen Bigelow, and K. Sreekumaran Nair. In vivo measurement of synthesis rate of multiple plasma proteins in humans. Am J Physiol Endocrinol Metab 291: E190-E197, 2006. First published January 31, 2006; doi:10.1152/ajpendo.00390.2005.—Advances in quantitative proteomics have facilitated the measurement of large-scale protein quantification, which represents net changes in protein synthesis and breakdown. However, measuring the rate of protein synthesis is the only way to determine the translational rate of gene transcripts. Here, we report a technique to measure the rate of incorporation of amino acids from ingested protein labeled with stable isotope into individual plasma proteins. This approach involves three steps: 1) production of stable isotope-labeled milk whey protein, oral administration of this intrinsically labeled protein, and subsequent collection of blood samples; 2) fractionation of the plasma and separation of the individual plasma proteins by a combination of anion exchange high-pressure liquid chromatography and gel electrophoresis; and 3) identification of individual plasma proteins by tandem mass spectrometry and measurement of stable isotopic enrichment of these proteins by gas chromatography-mass spectrometry. This method allowed the measurement of the fractional synthesis rate (FSR) of 29 different plasma proteins by using the same precursor pool. We noted a 30 -fold difference in FSR of different plasma proteins with a wide range of physiological functions. This approach offers a tremendous opportunity to study the regulation of plasma proteins in humans in many physiological and pathological states.
\end{abstract}

proteomics; plasma protein synthesis; phenylalanine; milk proteins; stable isotope

PLASMA PROTEINS play crucial physiological roles, and the alterations of certain plasma proteins indicate specific pathological states. Some of these changes are biomarkers of clinical disorders such as coronary artery disease (2) and cancer (25). However, only a limited number of plasma proteins have been measured and identified as markers of common clinical conditions, and the regulation of their plasma levels remains to be clearly defined. Recent technology based on in vitro stable isotope labeling methods (18) permits relative quantification of multiple plasma proteins. However, such techniques for measuring the relative concentrations of individual plasma proteins and peptide patterns in plasma do not allow us to understand the regulation at the molecular levels of plasma protein production and the maintenance of their levels. Gene array technology allows simultaneous measurement of the transcript levels of all known genes if appropriate tissue samples are available (26). This approach allows quantification of the transcript level changes of multiple genes and various func-

Address for reprint requests and other correspondence: K. S. Nair, Division of Endocrinology, Diabetes, Metabolism, and Nutrition, Mayo Clinic, 200 First St. SW, 5-194 Joseph, Rochester, MN 55905 (e-mail: nair.sree@mayo.edu). tional clusters in response to physiological interventions and pathological states. There are, however, substantial discrepancies between changes in transcript levels and protein expression levels $(9,15-17,19)$. The potential explanation for these discrepancies is the rapid turnover (synthesis and degradation) of proteins that may occur in many conditions so that concentrations of proteins may not reflect the actual synthesis rate, representing the translational rates of gene transcripts (28). It is therefore important not only to know the transcript and protein expression levels but also the rate at which the proteins are synthesized.

The measured abundance of a protein is the net result of its synthesis and breakdown. If these two processes are in equilibrium (despite upward or downward changes), the net concentration of the protein remains unchanged. During acute intervention, such as during a meal, although there is an increase in the rate of synthesis of specific proteins, such as albumin (11), there are no measurable changes in concentrations of many proteins because of their relatively slow turnover. Furthermore, protein quantification techniques are not sufficiently sensitive to detect changes that occur in very low abundance proteins, which may have a fast turnover rate. All of these limitations of in vitro labeling methods have led to the development of in vivo labeling of proteins for protein quantification, which has thus far only been applied to single-cell organisms $(10,29)$, cells in culture $(10,30)$, and to a limited extent in multicellular organisms such as Caenorhabditis elegans and Drosophila melanogaster (24). Proteomic strategies have also been developed for the relative measurement of protein turnover in chickens (12) and in cultures of single-cell organisms such as yeast (35) and bacteria (8). However, the aforementioned approaches require a high enrichment of proteins, which can be achieved by feeding animals for long periods with highly enriched isotopes or in single-cell organisms that have rapid turnover. Moreover, none of the above approaches provide a direct measurement of the synthesis rate of proteins, nor are they practical in human studies. Also, the aforementioned methods, as well the methods for protein quantification, do not have the sufficient precision for human studies, since these methodologies are highly dependent on the application of equal amounts of sample to be compared by mass spectrometry (MS) analysis. We have therefore developed an approach to simultaneously measure fractional synthesis rates of multiple plasma proteins and have demonstrated the method after a meal that contained intrinsically labeled proteins.

The costs of publication of this article were defrayed in part by the payment of page charges. The article must therefore be hereby marked "advertisement" in accordance with 18 U.S.C. Section 1734 solely to indicate this fact. 


\section{EXPERIMENTAL PROCEDURES}

Subjects. Six healthy adults ( 2 men and 4 women, average age $21.8 \pm 0.7 \mathrm{yr}$ ) were enrolled in the study. Average body mass index was $22.8 \pm 1.1 \mathrm{~kg} / \mathrm{m}^{2}$. Body composition was measured by dualenergy X-ray absorptiometry (23). Average fat-free mass (FFM) was $45.8 \pm 4.4 \mathrm{~kg}$. Only healthy people on physical examination and with normal fasting glucose and hepatic and renal function were studied.

Production of labeled milk protein. $\mathrm{L}-\left[\right.$ ring $\left.{ }^{13}{ }^{13} \mathrm{C}_{6}\right]$ phenylalanine (Phe; 99 atom percent excess) was purchased from Cambridge Isotope Laboratories (Cambridge Isotope Laboratories, Andover, MA) and, after demonstrating a negative rabbit test, was made into sterile solution. The whey protein was intrinsically labeled by infusing $\mathrm{L}-\left[\right.$ ring $\left.-{ }^{13} \mathrm{C}_{6}\right]$ Phe into lactating cows as previously reported (5). Briefly, a catheter was inserted percutaneously into the right jugular vein of the cow, and $\left[\right.$ ring- $\left.{ }^{13} \mathrm{C}_{6}\right]$ Phe was infused at a rate of 3 $\mathrm{mg} \cdot \mathrm{kg}^{-1} \cdot \mathrm{h}^{-1}$ using a peristaltic pump for $36 \mathrm{~h}$. The cow was milked every $6 \mathrm{~h}$ for $36 \mathrm{~h}$ during the infusion and for another $24 \mathrm{~h}$ after discontinuation of the infusion. The milk collected during the period of isotope infusion and $24 \mathrm{~h}$ after the infusion was pooled. The whey protein was separated using a standardized ultrafiltration technique as previously described (5). The whey protein was then freeze-dried and stored for the experiments. The Phe concentration in whey protein was estimated as $4 \%$, as was previously reported (37). Isotopic enrichment of $\left[{ }^{13} \mathrm{C}_{6}\right]$ Phe whey milk protein was determined by gas chromatography-quadrupole mass spectrometry (GC-QMS). The whey protein was hydrolyzed overnight, at $110^{\circ} \mathrm{C}$, using $6 \mathrm{M}$ hydrochloric acid as previously described (3). The technique used for processing of amino acids and GC-QMS analysis was the same for plasma free Phe and the amino acid derived from hydrolyzed whey protein. The isotopic enrichment of whey protein was estimated to be 17.8 molar percent excess (MPE).

Experimental design. The study protocol was reviewed and approved by the Mayo Foundation Institutional Review Board, and informed consent was obtained from each participant prior to the study. FFM was used for estimating meal energy and protein content. For 3 days before the study, all subjects received a weight-maintaining diet consisting of $20 \%$ protein, $50 \%$ carbohydrate, and $30 \%$ fat, which was provided by the General Clinical Research Center (GCRC) at Mayo Clinic. All subjects received a standard meal by 8 PM on the day before the study and then fasted until the morning in the GCRC. Ingestion of water was allowed. The femoral artery, femoral vein, and hepatic vein were catheterized by a vascular radiologist. Samples from the femoral vein were used for a separate set of analyses. Catheter sheaths were placed in the right femoral artery and femoral vein through the arterial sheath. Hepatic vein catheters were inserted under fluoroscopic control, and the approximate position was confirmed by use of an injectable, nonionic contrast medium. A slow infusion of normal saline maintained the patency of the catheters. The femoral artery and hepatic lines were used for collecting blood samples. After baseline blood samples were collected, subjects ingested $0.626 \mathrm{~g} / \mathrm{kg}$ FFM of whey protein intrinsically labeled with $\left[\right.$ ring- $\left.{ }^{13} \mathrm{C}_{6}\right] \mathrm{Phe}$ in combination with a similar amount of casein and $1.8 \mathrm{~g} / \mathrm{kg}$ FFM of lactose. This provided a total of $1.25 \mathrm{~g}$ protein $/ \mathrm{kg}$ FFM. Blood samples from the femoral artery and hepatic vein were collected at baseline and then every $20 \mathrm{~min}$ for $420 \mathrm{~min}$. Baseline and 400-min samples from the femoral artery were used to calculate enrichment for individual plasma proteins. The study was originally designed as a part of a larger physiological experiment, and the additional results will be reported separately.

Separation of individual plasma protein. Femoral arterial plasma samples from baseline and at $400 \mathrm{~min}$ of all subjects were used for the analysis of isotopic enrichment of individual plasma proteins. Each plasma sample was subjected to immunoglobulin removal (Affigel Protein-A; Bio-Rad, Hercules, CA) followed by albumin removal (SwellGel Blue; Pierce, Rockford, IL) to reduce the content of these highly abundant proteins. The recovery of proteins following deple- tion of plasma samples was $\sim 20 \%$, based on the estimated total protein concentration in plasma before and after depletion.

Each depleted plasma sample was fractionated further by use of anion exchange HPLC. Samples were loaded onto a PolyWAX LP (PolyLC Columbia USA, Columbia, MD) anion exchange column $(9.4 \mathrm{~mm} \times 10 \mathrm{~cm})$ and eluted using a Waters 600E HPLC system. The column was washed for $5 \mathrm{~min}$ with buffer $A$ (20 mM Tris, $\mathrm{pH} 7.5)$ followed by a gradient of 0 to $100 \%$ buffer $B(0.8 \mathrm{M}$ sodium acetate in buffer $A$ ) over $120 \mathrm{~min}$. The flow rate was $2 \mathrm{ml} / \mathrm{min}$, and the optical density (OD) was monitored at $280 \mathrm{~nm}$. Fifty fractions of $5 \mathrm{ml}$ each were collected. Each fraction was precipitated separately using $10 \%$ trichloroacetic acid. The precipitate from each fraction was dissolved in SDS sample buffer, and SDS-PAGE was performed on an 8-15\% acrylamide gel of $1.5 \mathrm{~mm}$ thickness. Each time point had 50 HPLC fractions, and a total of 600 fractions from six subjects were obtained and were subjected to gel electrophoresis (50 fractions were electrophoresed at one time with 25 fractions each on a single gel). The gels were later stained with Coomassie blue. Pairs of 37 gel bands, which were the best resolved and intense from both time points, obtained from 50 fractions of each time point were excised and analyzed for protein identification by tandem mass spectrometry (LC-MS-MS) and for isotopic enrichment by GC-QMS. Figure 1 displays only the lines (HPLC fractions) showing the gel bands that were used for the study. The rest of the HPLC fractions either did not produce any protein gel bands or showed gel bands that were not considered optimal for analysis because of the difficulty in reaching correct protein identification. Although we analyzed a total of 37 gel bands from each sample (50 HPLC fractions), only 29 were identified as single protein and therefore used for isotopic measurement.

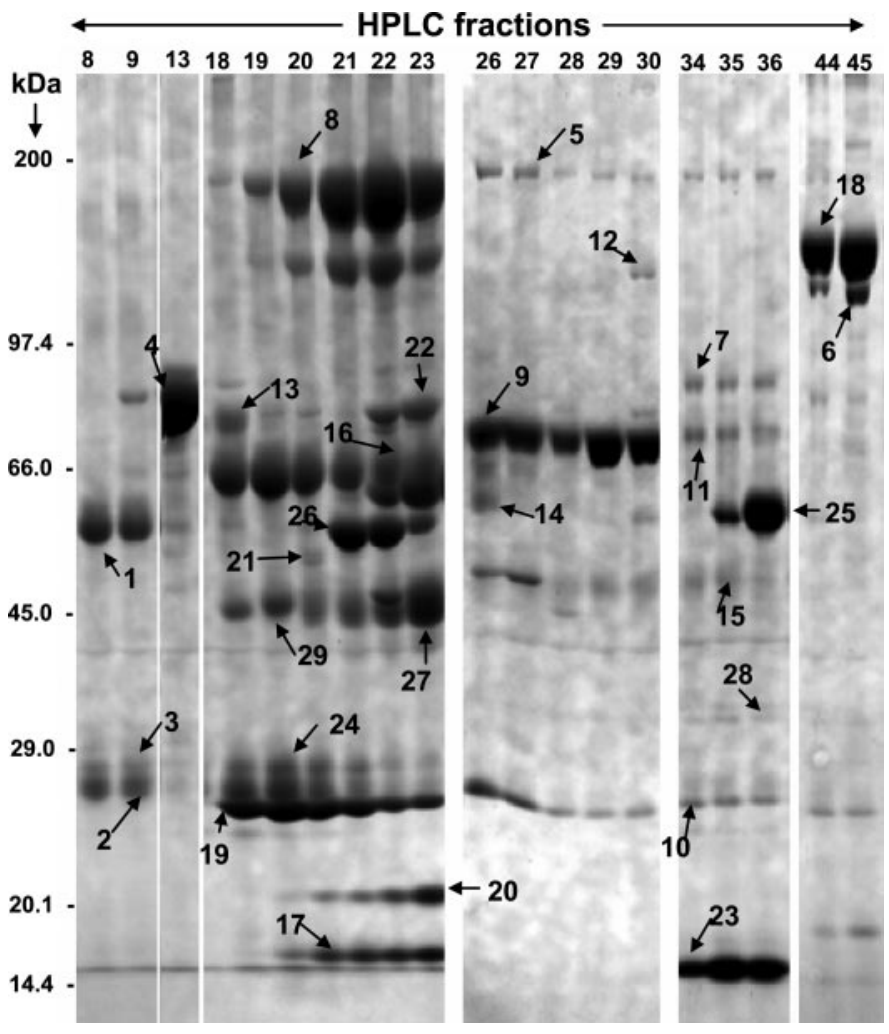

Fig. 1. SDS-PAGE of anion exchange HPLC fractions of plasma proteins. Plasma proteins were first fractionated into 50 HPLC fractions, and proteins from each fraction were precipitated and subjected to SDS-PAGE on $8-15 \%$ gradient gels using the Bio-Rad Protean-II system. Gels were stained with Coomassie blue to visualize protein gel bands. The figure displays only the lines (HPLC fractions) showing the gel bands that were used for protein identification and isotopic enrichment analysis. The gel bands are numbered to match the protein serial numbers in Tables 2 and 3 . 
Protein identification by LC-MS-MS. Gel bands were subjected to in-gel reduction and alkylation, followed by trypsin digestion, as previously described $(21,36)$. Peptides were extracted three times, first by adding $2 \%$ trifluoroacetic acid (TFA) in water to the digest mixture and then by an equal volume of $60 \%$ acetonitrile- $0.1 \%$ TFA- $40 \%$ water followed by a final extraction with $100 \%$ acetonitrile. Extracts were dried by evaporation (Savant Speedvac) to remove the organic solvent. Samples were dissolved in $0.1 \%$ formic acid- $2 \%$ acetonitrile solution just before injection into the mass spectrometer.

MS analyses were done on a linear ion-trap quadrupole mass spectrometer (LTQ; Thermo Electron, Franklin, MA). The digested peptides were introduced into the LTQ through an automated nanoscale liquid chromatography system (LC Packings, Sunnyvale, CA). The chromatographic separation was performed on a $100-\mu \mathrm{m}$ inside diameter $\times 15$-cm $\mathrm{C}_{18}$ column (Zorbax; Agilent Technologies, Palo Alto, CA) with a linear gradient elution from $100 \%$ buffer $A$ $(0.1 \%$ formic acid-acetonitrile, $98: 2, \mathrm{vol} / \mathrm{vol})$ to $60 \%$ buffer $B(0.1 \%$ formic acid-acetonitrile, 2:98, vol/vol) in $60 \mathrm{~min}$. The collected data were compared against a nonredundant human database by use of TurboSequest software (University of Washington). Peptide mass tolerance and fragment mass tolerance were set at 1.4 and $0.5 \mathrm{Da}$, respectively. Identification of individual proteins was confirmed by triplicate analysis of gels bands of baseline samples from three different study subjects.

The tissue origin of each identified proteins as well as their functions were obtained from Human Protein Reference Database (33) and Swiss-Protein database.

Isotopic enrichment of individual plasma proteins derived from gel bands. Isotopic enrichment of Phe derived from hydrolysis of plasma proteins by GC-QMS was measured as described previously $(7,32)$. For GC-QMS analysis, gel pieces were washed several times with deionized water and hydrolyzed overnight at $110^{\circ} \mathrm{C}$ in $6 \mathrm{M}$ hydrochloric acid. Amino acids from the hydrolyzed gel pieces were purified over an AG-50W cation exchange column, eluted with $4 \mathrm{M}$ ammonium hydroxide, and dried by evaporation. Methyl esters were made before acylation with heptafluorobutyric anhydride. Derivatives were dried and resuspended in ethyl acetate for GC-QMS analysis on a Triple Stage Quadrupole (Finnigan TSQ 7000; Thermo Electron) under positive chemical ionization with ammonia gas. Amino acid (Phe ester) separation was carried out on a DB5-ms $30 \mathrm{~m} \times 0.25$ $\mathrm{mm} \times 0.25 \mu \mathrm{m}$ capillary column (Agilent Technologies) in the GC oven with helium flow rate of $3 \mathrm{ml} / \mathrm{min}$ and the temperature ramp as follows: $100-152^{\circ} \mathrm{C}$ at $5 \% \mathrm{~min}, 152-154^{\circ} \mathrm{C}$ at $1 \% \mathrm{~min}$, and $154-300^{\circ} \mathrm{C}$ at $20 \% \mathrm{~min}$. Selected ion monitoring was performed in profile mode at $m / z, 396(M+3)$ and $m / z, 399(M+6)$ for $\left[{ }^{12} \mathrm{C}\right] \mathrm{Phe}$ and $\left[{ }^{13} \mathrm{C}_{6}\right] \mathrm{Phe}$, respectively $(7,32)$. Enrichment (molar percent excess, MPE) was calculated using an equation obtained from a six-point calibration curve. The regression analysis of theoretical and measured enrichment gave regression coefficient $\left(r^{2}\right)$ of 0.9998 . Replicate measurements of isotopic enrichment of proteins collected from five separate gel bands after gel electrophoresis (as described above) were performed to determine reproducibility (Table 1 ). Ten replicate measurements in each of five different protein bands showed a coefficient of variation ranging from 3.4 to $6.5 \%$.

Isotopic enrichment of free Phe in plasma. Isotopic enrichment of free $\left[{ }^{13} \mathrm{C}_{6}\right] \mathrm{Phe}$ in plasma was determined by GC-QMS. We analyzed 23 samples (at $-20 \mathrm{~min}$ and every $20 \mathrm{~min}$ until $420 \mathrm{~min}$, i.e., 23 samples from each subject and total 276 samples). Each plasma sample $(0.1 \mathrm{ml})$ was acidified using $0.1 \mathrm{ml}$ of $50 \%$ acetic acid, and this mixture was passed through an AG-50W cation exchange column. After the column was washed with water, the amino acids were eluted with $4 \mathrm{M}$ ammonium hydroxide followed by evaporation to dryness using a centrifugal evaporator. The tert-butyldimethylsiloxy derivative was prepared and, after removal of excess solvent, resuspended in n-decane for analysis by GC-MS (5973N GC/MS; Agilent Technologies) under electron ionization conditions. Chromatographic separation was carried out on a $30 \mathrm{~m} \times 0.25 \mathrm{~mm} \times 0.25 \mu \mathrm{m}$ DB5-ms
Table 1. Reproducibility of very low level isotopic enrichment measurements from gel bands

\begin{tabular}{ccc}
\hline \hline Band & L- $\left[\right.$ ring $\left.{ }^{13} \mathrm{C}_{6}\right] \mathrm{Phe}, \mathrm{MPE} *$ & $\mathrm{CV}, \%$ \\
\hline 1 & $0.0640 \pm 0.0008$ & 3.73 \\
2 & $0.0523 \pm 0.0008$ & 5.10 \\
3 & $0.1131 \pm 0.0030$ & 5.75 \\
4 & $0.2901 \pm 0.0053$ & 3.41 \\
5 & $0.1246 \pm 0.0025$ & 6.46 \\
& & $4.89 \pm 0.58($ mean $\pm \mathrm{SE})$
\end{tabular}

*Values are means \pm SE; $n=10$ replicates. MPE, mole percent excess. One representative plasma sample at $400 \mathrm{~min}$ after meal ingestion was run $50 \mu \mathrm{g}$ each in 10 wells on an $8-15 \%$ SDS-PAGE. Five separate gel bands (1-5) were excised from each of the 10 lanes of the gel, processed, and performed isotopic enrichment analysis on by GC-MS as described in EXPERIMENTAL PROCEDURES.

capillary column (Agilent Technologies) using helium as carrier gas at $2 \mathrm{ml} / \mathrm{min}$. A ramped temperature program was used: $120-175^{\circ} \mathrm{C}$ at $20 \% \mathrm{~min}, 175-195^{\circ} \mathrm{C}$ at $10^{\circ} / \mathrm{min}$, and $195-300^{\circ} \mathrm{C}$ at $30 \% \mathrm{~min}$. A limited scan of the $[M-57]^{+}$region was performed, $m / z$ 336-344 with 10 $\mathrm{ms}$ dwell for each ion and triplicate injections of each label for each plasma sample compared with similar profiles collected for natural abundance Phe. The MPE of $\left[{ }^{13} \mathrm{C}_{6}\right]$ Phe was calculated above background, as previously described (20).

Calculation of FSR of plasma proteins. We subtracted the baseline natural isotopic abundance of $\left[{ }^{13} \mathrm{C}_{6}\right] \mathrm{Phe}$ in plasma proteins from those samples collected $400 \mathrm{~min}$ after the meal $\left(\mathrm{I}_{\mathrm{e}}\right)$. The integrated values for plasma $\left[{ }^{13} \mathrm{C}_{6}\right]$ Phe isotopic enrichment of all time points after the administration of the labeled meal were used as the precursor enrichment $\left(\mathrm{P}_{\mathrm{e}}\right)$. The calculation of protein FSR has been described previously (27). The equation used is as follows: FSR $(\% / \mathrm{h})=\left[\mathrm{I}_{\mathrm{e}} /\right.$ $\left.\left(\mathrm{P}_{\mathrm{e}} \cdot t\right)\right] \cdot 100$, in which $t$ represents time $(6.67 \mathrm{~h})$.

We used isotopic enrichment (integrated values for $6.67 \mathrm{~h}$ ) of hepatic venous plasma $\left(\mathrm{P}_{\mathrm{e}}\right)$ as precursor for FSR calculation of proteins derived from liver and femoral arterial plasma enrichment (Pe) to calculate FSR of proteins from tissues other than liver.

Statistical analysis. All values are expressed as means \pm SE. Comparison of plasma Phe isotopic enrichment values between hepatic vein and femoral artery was analyzed using a paired $t$-test.

\section{RESULTS}

Isotopic enrichment of plasma Phe and Phe concentration. As expected, immediately following the ingestion of the meal, both arterial and hepatic venous isotopic Phe enrichment values and Phe concentration increased, and enrichment value remained above natural abundance until the end of the study (Fig. 2). In contrast, plasma Phe concentration returned near baseline by $360 \mathrm{~min}$. Although both arterial and venous Phe concentrations were similar, the enrichment values were higher in the hepatic vein from 20 to $280 \mathrm{~min}$ (4.44 \pm 0.24 average MPE for hepatic vein vs. $3.57 \pm 0.17$ for femoral artery, $P<$ 0.001).

Isotopic enrichment of individual plasma proteins and precursors. The integrated values of femoral arterial $\left[{ }^{13} \mathrm{C}_{6}\right] \mathrm{Phe}$ enrichment were significantly lower $(2.92 \pm 0.28)$ than those of hepatic venous enrichment $(3.57 \pm 0.33, P<0.001)$. The isotopic enrichment of each of the 29 proteins (Table 2) showed a wide range in enrichment values (0.03 to 0.66 MPE).

Identified proteins and their functions. The proteins identified with corresponding sequest score, percent coverage, and numbers of peptides are shown in Table 2. The functions, as well as the origins, of the proteins whose synthesis rates are measured are given in Table 3. The majority of the proteins 
A

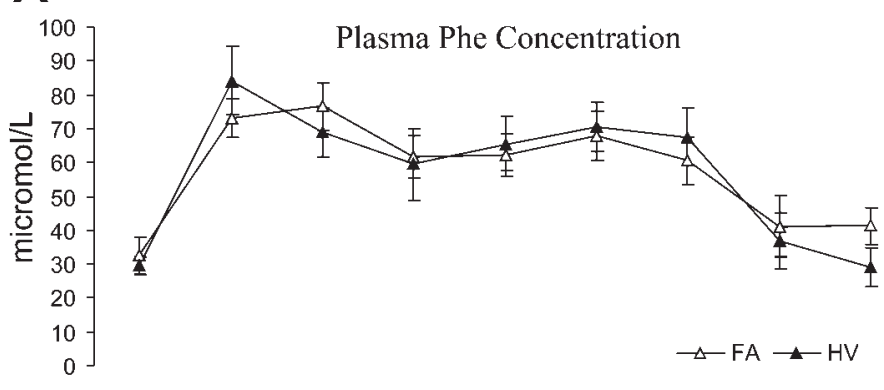

B

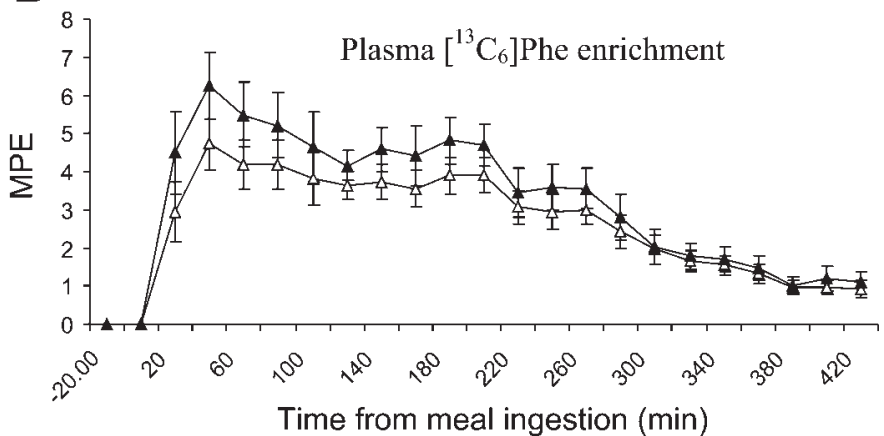

Fig. 2. Plasma Phe concentration and Phe isotopic enrichment following the ingestion of L- $\left[\right.$ ring- $\left.{ }^{13} \mathrm{C}_{6}\right]$ Phe-labeled whey protein. $A$ : plasma Phe concentration from femoral artery (FA) and hepatic vein (HV) of 9 time points from 0 to 7 h. $B$ : plasma $\left[{ }^{13} \mathrm{C}_{6}\right]$ Phe enrichment from FA and $\mathrm{HV}$ starting from -20 min and followed by meal $(0 \mathrm{~min})$ for every $20 \mathrm{~min}$ up to $7 \mathrm{~h}$. MPE, mole percent excess. Data points are means $\pm \mathrm{SE} ; n=6$. identified are of liver origin, and others are derived from either B lymphocytes or the intestine.

FSR of plasma proteins. FSR $(\% / \mathrm{h})$ of 29 plasma proteins are given in Fig. $3(1.13 \pm 0.16$ to $30.91 \pm 6.75 \% / \mathrm{h})$, demonstrating an $\sim 30$-fold difference.

\section{DISCUSSION}

We measured in vivo FSRs of 29 plasma proteins in healthy people from the rate of incorporation of labeled Phe derived from intrinsically labeled milk protein administered orally. With this technique we were able to observe a 30 -fold range in the synthesis rate of plasma proteins. The measurement of FSRs of proteins represents the best measurement of translational rates of gene transcripts, thus offering a potential opportunity to understand the in vivo regulation of specific genes. Unlike previous approaches, limited to the measurement of synthesis rates of only a few plasma proteins $(13,22)$, here we utilized a large-scale protein purification approach in combination with mass spectrometry to identify the purified proteins as well as to measure the stable isotopic abundance of Phe in these proteins. We measured postprandial synthesis rates of these proteins not only because the postprandial period is longer than the fasted state but also because the period represents the net anabolic phase.

The use of intrinsically labeled milk whey protein has some advantages in measuring postprandial FSR of plasma proteins. Both tracer amino acid and amino acids derived from the ingested protein appear simultaneously when ingested protein is labeled with the tracer. In contrast, free amino acid tracer

Table 2. Plasma proteins identified and their respective $\left[{ }^{13} C_{6}\right]$ Phe enrichment

\begin{tabular}{|c|c|c|c|c|c|c|}
\hline 2 & Immunoglobulin kappa light chain & $0.03 \pm 0.00$ & 89.27 & 21669337 & 9 & 17 \\
\hline 5 & MAHU alpha2-macroglobulin precursor & $0.05 \pm 0.01$ & 520.29 & 4557225 & 52 & 68 \\
\hline 6 & Ceruloplasmin & $0.06 \pm 0.01$ & 280.23 & 4557485 & 28 & 17 \\
\hline 7 & MHHUM Ig mu chain c region, membrane-bound splice form, human & $0.07 \pm 0.01$ & 447.26 & 7428606 & 45 & 22 \\
\hline 10 & Immunoglobulin J chain & $0.08 \pm 0.01$ & 40.16 & 21489959 & 4 & 34 \\
\hline 11 & A chain A, crystal structure of human serum albumin & $0.11 \pm 0.01$ & 309.26 & 3212456 & 31 & 26 \\
\hline 12 & Complement component 3 precursor; acylation-stimulating protein cleavage & $0.13 \pm 0.02$ & 70.20 & 4557385 & 7 & 28 \\
\hline 13 & Hemopexin & $0.11 \pm 0.02$ & 60.21 & 386789 & 6 & 25 \\
\hline 14 & A1AT_human alpha1-antitrypsin precursor & $0.14 \pm 0.03$ & 290.28 & 1703025 & 29 & 28 \\
\hline 15 & Apolipoprotein A-IV precursor & $0.14 \pm 0.02$ & 200.22 & 4502151 & 20 & 48 \\
\hline 16 & Albumin precursor; pro0883 protein & $0.15 \pm 0.05$ & 189.24 & 23307793 & 19 & 70 \\
\hline 22 & Alpha1B-glycoprotein & $0.32 \pm 0.02$ & 140.20 & 23503038 & 14 & 12 \\
\hline 23 & Transthyretin (prealbumin, amyloidosis type i) & $0.24 \pm 0.06$ & 240.30 & 4507725 & 24 & 54 \\
\hline 24 & Apolipoprotein A-1 precursor & $0.17 \pm 0.02$ & 439.27 & 4557321 & 44 & 64 \\
\hline 25 & Alpha2HS-glycoprotein & $0.35 \pm 0.02$ & 100.30 & 4502005 & 10 & 17 \\
\hline 26 & VYHUD vitamin D-binding protein precursor & $0.38 \pm 0.04$ & 159.20 & 139641 & 16 & 51 \\
\hline 27 & Haptoglobin & $0.45 \pm 0.03$ & 322.30 & 4826762 & 35 & 49 \\
\hline 28 & B chain B, the structure of human retinol-binding protein with its carrier protein & $0.52 \pm 0.01$ & 39.23 & 4558176 & 4 & 22 \\
\hline 29 & Zinc-alpha2-glycoprotein precursor & $0.66 \pm 0.11$ & 350.30 & 72059 & 35 & 34 \\
\hline
\end{tabular}

Plasma proteins were identified by tandem mass spectrometry. Identification was confirmed by triplicate analysis of baseline samples from 3 different individuals. Sequest score, accession no., no. of peptides, and \%coverage are from a representative analysis. Isotopic enrichment values (MPE \pm SE) are from all 6 study subjects analyzed by GC-MS. 
Table 3. Plasma proteins, whose FSRs were calculated in the current study

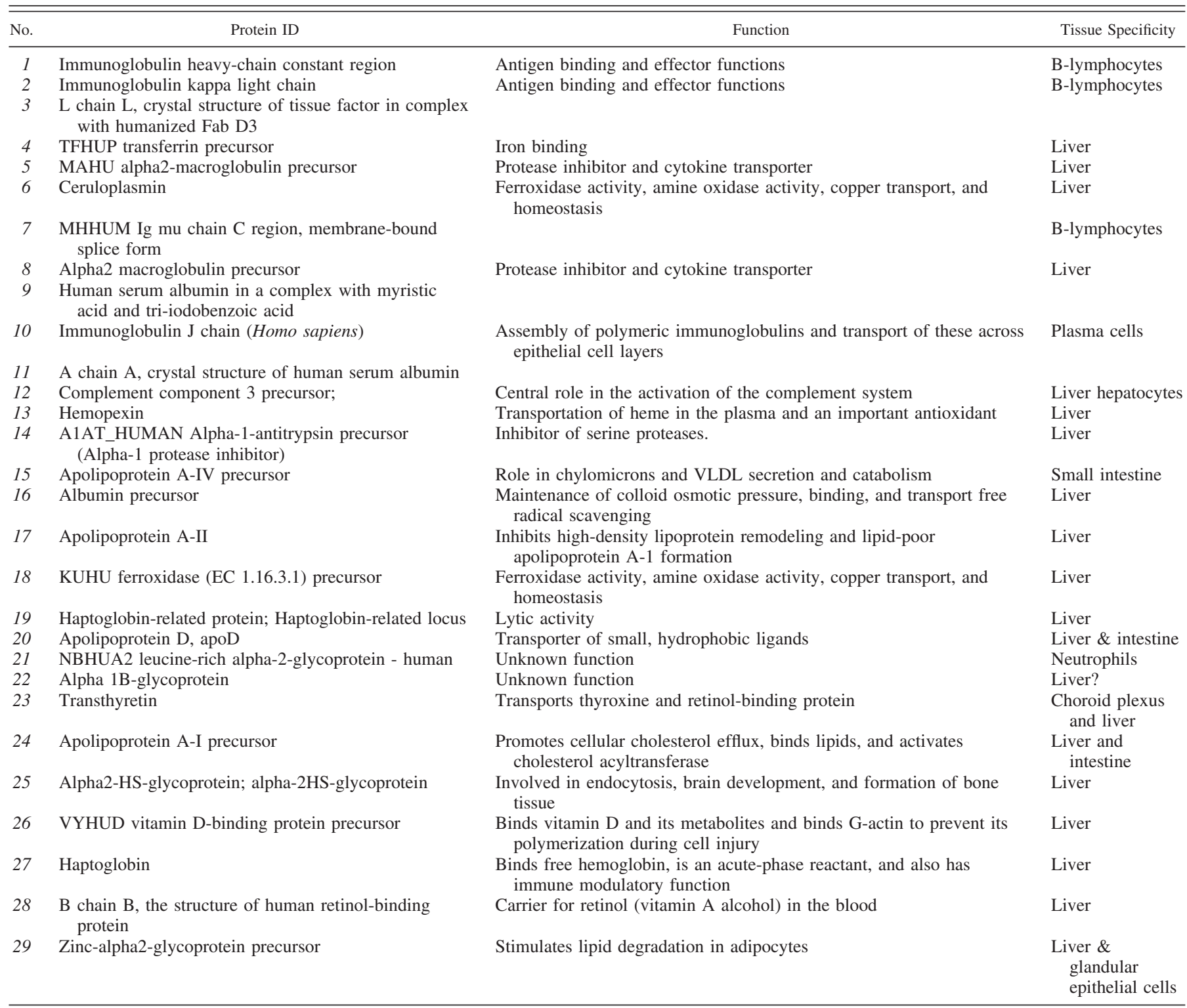

Corresponding functions along with their site of synthesis.

mixed with orally ingested protein appears and disappears faster than amino acids derived from ingested protein because of the time needed to digest the ingested protein by pancreatic enzymes (6). As a result, the use of free amino acid tracer in blood is a better representation of the actual precursor of protein synthesis in liver when the ingested protein is labeled with amino acid tracer. Another approach is using an intravenous free amino acid tracer to measure postprandial plasma protein synthesis. The problem with this approach is that a meal can dramatically dilute the intravenously administered tracer to low levels due to an increase in unlabeled amino acids appearing from meal proteins (14). The dilution of the tracer enrichment occurring in the hepatic circulation by the mealderived amino acids transiting through the portal circulation cannot be fully assessed when the tracer is infused systemically. We circumvented this problem by having subjects ingest the tracer-bound protein $\left[\right.$ ring- $\left.{ }^{13} \mathrm{C}_{6}\right]$ Phe-whey as a meal.
We used the hepatic vein free Phe label as precursor for calculating FSR of liver-derived proteins, whereas for other proteins we used arterial label as the precursor. Although the Phe enrichment in hepatic vein and femoral artery was not in a steady state following meal ingestion, the average value is likely to represent the true precursor enrichment values. We used the same precursor values for FSR calculations of all plasma proteins, and therefore the fold differences that we reported are valid. We also determined the differences in isotopic enrichment between arterial and hepatic vein $\left[{ }^{13} \mathrm{C}_{6}\right]$ Phe and found an average $18 \%$ lower enrichment in arterial plasma. This can result in some underestimation of FSR of liver-derived plasma proteins when arterial plasma Phe label is used as precursor. The lower isotopic enrichment of arterial Phe can be explained by unlabeled Phe appearing from degradation of proteins from the peripheral tissues. Theoretically, the hepatic vein that drains blood from liver is likely to 


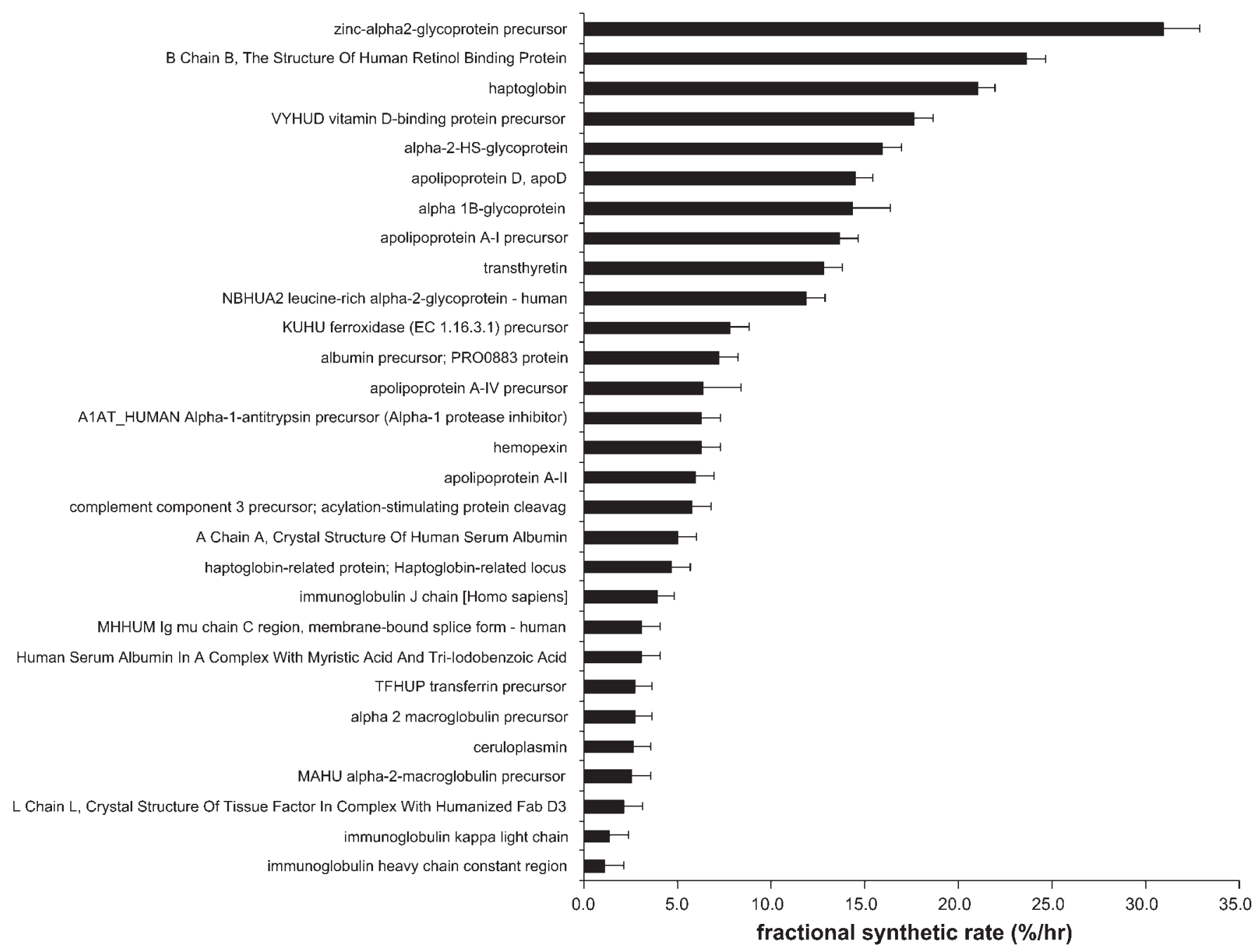

Fig. 3. Fractional synthesis rates (FSR) of 29 plasma proteins. Proteins are arranged in hierarchical order of their FSR, showing the highest value for zinc $\alpha 2$ glycoprotein and with immunoglobulin heavy-chain constant region showing the lowest. The FSR of each protein was calculated using precursor pool enrichment from either hepatic vein for proteins of hepatic origin or femoral artery for proteins of nonhepatic origin.

represent hepatic $\left[{ }^{13} \mathrm{C}_{6}\right] \mathrm{Phe}$ enrichment in the intracellular compartment of the liver. This assumption is supported by results from previous studies $(1,4)$ demonstrating that liver tissue fluid and tRNA leucine enrichment are best represented by arterial ketoisocaproate enrichment, which is not different from the hepatic venous leucine enrichment. We appreciate that it is not practical to measure hepatic venous plasma isotopic enrichment for most human studies. The current results demonstrated that the difference in enrichment of hepatic and peripheral Phe enrichment is small. It remains to be determined whether a similar relationship exists for other amino acid tracers as well.

In the present study, we chose anion exchange HPLC as the first dimension separation based on charge and SDS-PAGE as the second dimension to separate plasma proteins instead of a two-dimensional gel electrophoresis to obtain sufficient protein concentration in a single gel band for detection with GC-QMS. The individual plasma proteins were identified by MS-MS as described in EXPERIMENTAL PROCEDURES. In the present study, we selected only 29 gel bands, which were intense and resolved clearly, for analysis. With those bands, we could analyze $\sim 10 \%$ of the known plasma proteins, which could be separated and identified using gel separation techniques (34). Our separation approach yielded individual proteins for the analysis. The combination of two one-step procedures used in the present study is not sufficient to isolate the maximal number of plasma proteins. The main difficulty to overcome is the complexity and tremendous variation in individual plasma protein abundance; e.g., albumin is $10^{9}$-fold more abundant in plasma than troponin T. A combination of different ranges of liquid chromatography columns along with electrophoresis methods can separate and isolate medium- and low-abundance plasma proteins. However, the present report is the first, to our knowledge, to report in vivo synthesis rates of a large number of plasma proteins in humans. Ten replicate experiments from five separate gel bands demonstrated the high precision of the measurement, which offers the opportunity to detect small changes in plasma protein enrichment (Table 1).

We determined the function and origin of these plasma proteins (Table 3) from the Human Protein Reference Database (http://www.hprd.org/query) and Swiss-Protein database (http://www.expasy.ch/cgi-bin/sprot-search-ful). We found 
that proteins with immunologic functions, such as immunoglobulin heavy-chain constant, and immunoglobulin $\kappa$-chain have more than 10-fold lower synthesis rates than some of the binding proteins, such as retinol-binding proteins and vitamin D-binding proteins. These binding proteins are critical in transporting nutrient molecules, such as vitamin D and retinol, or hormones, such as thyroxine. The production of these proteins is critical to preventing sudden increases in the concentration of free molecules with major functional consequences. In general, it appears that most of the proteins that we identified with a fast FSR are proteins, such as apolipoproteins, that are necessary for transferring lipids or fatty acids to different locations, or acute phase reaction proteins, such as haptoglobin.

The current approach offers the opportunity to determine the effect of various physiological factors, such as growth, aging, hormones, and substrates, as well as pathological states on the rate of synthesis of various circulating proteins. Because these changes are measures of the translational rates of transcripts to proteins, they can be used to obtain precise mechanistic information of the effect of physiological interventions and pathological states. It is conceivable that lack of changes in concentrations of proteins between two study conditions may occur if synthesis and degradation rates change in the same direction at the same magnitude. For example, the synthesis and degradation rates of a single protein or cluster of proteins with similar functions could increase 10-fold in a specific condition with a major effect on functions but no measurable changes in the protein concentrations.

In conclusion, the approach described in the present study enables the measurement of synthesis rates of multiple plasma proteins. Our study uses the labeling of ingested protein to measure the rate at which labeled amino acid is incorporated into multiple plasma proteins, thus enabling us to measure their synthesis rates following a meal. Similar techniques could be used to measure synthesis rates of multiple proteins in the postabsorptive state with intravenous administration of tracers, as has been reported by many authors for the measurement of one or two plasma proteins (31). In summary, we measured the postprandial synthesis rates of 29 plasma proteins by in vivo labeling of these proteins, thus demonstrating a 30-fold difference in their synthesis rates. Simultaneous measurement of transcript levels and FSR in the same tissue during interventions will allow one to determine whether the intervention affected translation or transcription.

\section{ACKNOWLEDGMENTS}

We appreciate support from the GCRC Nursing and Dietetic staff and the skilled technical support of Charles Ford, Dawn Morse, and Jane Kahl.

\section{GRANTS}

This study was supported by grants from the National Institutes of Health: RO1 D-41973, RO1 AG-09531, and MO1 RR-00585 and the Mayo Foundation.

\section{REFERENCES}

1. Ahlman B, Charlton M, Fu A, Berg C, O'Brien P, and Nair KS. Insulin's effect on synthesis rates of liver proteins. A swine model comparing various precursors of protein synthesis. Diabetes 50: 947-954, 2001 .

2. Anderson L. Candidate-based proteomics in the search for biomarkers of cardiovascular disease. J Physiol 563: 23-60, 2005.
3. Balagopal P, Ford GC, Ebenstein DB, Nadeau DA, and Nair KS. Mass spectrometric methods for determination of [13C]leucine enrichment in human muscle protein. Anal Biochem 239: 77-85, 1996.

4. Barazzoni R, Meek SE, Ekberg K, Wahren J, and Nair KS. Arterial KIC as marker of liver and muscle intracellular leucine pools in healthy and type 1 diabetic humans. Am J Physiol Endocrinol Metab 277: E238-E244, 1999.

5. Boirie Y, Fauquant $\mathbf{J}$, Rulquin $\mathbf{H}$, Maubois $\mathbf{J L}$, and Beaufrere $\mathbf{B}$. Production of large amounts of [13C]leucine-enriched milk proteins by lactating cows. J Nutr 125: 92-98, 1995.

6. Boirie Y, Gachon P, Corny S, Fauquant J, Maubois JL, and Beaufrère B. Acute postprandial changes in leucine metabolism as assessed with an intrinsically labeled milk protein. Am J Physiol Endocrinol Metab 271: E1083-E1091, 1996.

7. Calder AG, Anderson SE, Grant I, McNurlan MA, and Garlick PJ. The determination of low d5-phenylalanine enrichment (0.002-0.09 atom percent excess), after conversion to phenylethylamine, in relation to protein turnover studies by gas chromatography/electron ionization mass spectrometry. Rapid Commun Mass Spectrom 6: 421-424, 1992.

8. Cargile BJ, Bundy JL, Grunden AM, and Stephenson JL Jr. Synthesis/degradation ratio mass spectrometry for measuring relative dynamic protein turnover. Anal Chem 76: 86-97, 2004.

9. Chen G, Gharib TG, Huang CC, Taylor JM, Misek DE, Kardia SL, Giordano TJ, Iannettoni MD, Orringer MB, Hanash SM, and Beer DG. Discordant protein and mRNA expression in lung adenocarcinomas. Mol Cell Proteom 1: 304-313, 2002.

10. Conrads TP, Alving K, Veenstra TD, Belov ME, Anderson GA, Anderson DJ, Lipton MS, Pasa-Tolic L, Udseth HR, Chrisler WB, Thrall BD, and Smith RD. Quantitative analysis of bacterial and mammalian proteomes using a combination of cysteine affinity tags and 15N-metabolic labeling. Anal Chem 73: 2132-2139, 2001.

11. De Feo P, Horber FF, and Haymond MW. Meal stimulation of albumin synthesis: a significant contributor to whole body protein synthesis in humans. Am J Physiol Endocrinol Metab 263: E794-E799, 1992.

12. Doherty MK, Whitehead C, McCormack H, Gaskell SJ, and Beynon RJ. Proteome dynamics in complex organisms: using stable isotopes to monitor individual protein turnover rates. Proteomics 5: 522-533, 2005.

13. Fu AZ, Morris JC, Ford GC, and Nair KS. Sequential purification of human apolipoprotein B-100, albumin, and fibrinogen by immunoaffinity chromatography for measurement of protein synthesis. Anal Biochem 247: 228-236, 1997.

14. Gibson NR, Fereday A, Cox M, Halliday D, Pacy PJ, and Millward DJ. Influences of dietary energy and protein on leucine kinetics during feeding in healthy adults. Am J Physiol Endocrinol Metab 270: E282E291, 1996.

15. Greenbaum D, Colangelo C, Williams K, and Gerstein M. Comparing protein abundance and mRNA expression levels on a genomic scale. Genome Biol 4: 117, 2003.

16. Griffin TJ, Gygi SP, Ideker T, Rist B, Eng J, Hood L, and Aebersold R. Complementary profiling of gene expression at the transcriptome and proteome levels in Saccharomyces cerevisiae. Mol Cell Proteom 1: 323 333, 2002.

17. Gygi SP, Rist B, and Aebersold R. Measuring gene expression by quantitative proteome analysis. Curr Opin Biotechnol 11: 396-401, 2000.

18. Gygi SP, Rist B, Gerber SA, Turecek F, Gelb MH, and Aebersold R. Quantitative analysis of complex protein mixtures using isotope-coded affinity tags. Nat Biotechnol 17: 994-999, 1999.

19. Gygi SP, Rochon Y, Franza BR, and Aebersold R. Correlation between protein and mRNA abundance in yeast. Mol Cell Biol 19: 1720-1730, 1999.

20. Halliday D and Ford GC. Stable Isotopes in Clinical Investigations. In: Clinical Biochemistry: Principles, Methods, Applications, edited by Lawson AM. New York: Walter de Gruyter, 1989, p. 684-726.

21. Hellman U, Wernstedt C, Gonez J, and Heldin CH. Improvement of an "In-Gel" digestion procedure for the micropreparation of internal protein fragments for amino acid sequencing. Anal Biochem 224: 451-455, 1995.

22. Jahoor F, Sivakumar B, Del Rosario M, and Frazer EM. Isolation of acute-phase proteins from plasma for determination of fractional synthesis rates by a stable isotope tracer technique. Anal Biochem 236: 95-100, 1996.

23. Jensen MD, Kanaley JA, Roust LR, O'Brien PC, Braun JS, Dunn WL, and Wahner HW. Assessment of body composition with use of dual-energy x-ray absorptiometry: evaluation and comparison with other methods. Mayo Clin Proc 68: 867-873, 1993. 
24. Krijgsveld J, Ketting RF, Mahmoudi T, Johansen J, Artal-Sanz M, Verrijzer CP, Plasterk RH, and Heck AJ. Metabolic labeling of C. elegans and D. melanogaster for quantitative proteomics. Nat Biotechnol 21: 927-931, 2003.

25. Locke $\mathbf{S}$ and Figeys D. Techniques for the optimization of proteomic strategies based on head column stacking capillary electrophoresis. Anal Chem 72: 2684-2689, 2000.

26. Lockhart DJ, Dong H, Byrne MC, Follettie MT, Gallo MV, Chee MS, Mittmann M, Wang C, Kobayashi M, Horton H, and Brown EL. Expression monitoring by hybridization to high-density oligonucleotide arrays. Nat Biotechnol 14: 1675-1680, 1996.

27. Nair KS, Halliday D, and Griggs RC. Leucine incorporation into mixed skeletal muscle protein in humans. Am J Physiol Endocrinol Metab 254: E208-E213, 1988

28. Nair KS, Jaleel A, Asmann YW, Short KR, and Raghavakaimal S. Proteomic research: potential opportunities for clinical and physiological investigators. Am J Physiol Endocrinol Metab 286: E863-E874, 2004

29. Oda Y, Huang K, Cross FR, Cowburn D, and Chait BT. Accurate quantitation of protein expression and site-specific phosphorylation. Proc Natl Acad Sci USA 96: 6591-6596, 1999.

30. Ong SE, Blagoev B, Kratchmarova I, Kristensen DB, Steen H, Pandey A, and Mann M. Stable isotope labeling by amino acids in cell culture, SILAC, as a simple and accurate approach to expression proteomics. $\mathrm{Mol}$ Cell Proteom 1: 376-386, 2002.

31. Pacy PJ, Read M, and Halliday D. Influence of insulin on albumin and non-albumin protein fractional synthetic rates in post-absorptive type I diabetic patients. Eur J Clin Nutr 44: 343-349, 1990.

32. Patterson BW, Zhang XJ, Chen Y, Klein S, and Wolfe RR. Measurement of very low stable isotope enrichments by gas chromatography/mass spectrometry: application to measurement of muscle protein synthesis. Metab Clin Exper 46: 943-948, 1997.

33. Peri S, Navarro JD, Amanchy R, Kristiansen TZ, Jonnalagadda CK, Surendranath V, Niranjan V, Muthusamy B, Gandhi TK, Gronborg M, Ibarrola N, Deshpande N, Shanker K, Shivashankar HN, Rashmi BP, Ramya MA, Zhao Z, Chandrika KN, Padma N, Harsha HC, Yatish AJ, Kavitha MP, Menezes M, Choudhury DR, Suresh S, Ghosh N, Saravana R, Chandran S, Krishna S, Joy M, Anand SK, Madavan V, Joseph A, Wong GW, Schiemann WP, Constantinescu SN, Huang L, Khosravi-Far R, Steen H, Tewari M, Ghaffari S, Blobe GC, Dang CV, Garcia JG, Pevsner J, Jensen ON, Roepstorff P, Deshpande KS, Chinnaiyan AM, Hamosh A, Chakravarti A, and Pandey A. Development of human protein reference database as an initial platform for approaching systems biology in humans. Genome Res 13: 2363-2371, 2003.

34. Pieper R, Gatlin CL, Makusky AJ, Russo PS, Schatz CR, Miller SS, Su Q, McGrath AM, Estock MA, Parmar PP, Zhao M, Huang ST, Zhou J, Wang F, Esquer-Blasco R, Anderson NL, Taylor J, and Steiner S. The human serum proteome: display of nearly 3700 chromatographically separated protein spots on two-dimensional electrophoresis gels and identification of 325 distinct proteins. Proteomics 3: 1345-1364, 2003.

35. Pratt JM, Petty J, Riba-Garcia I, Robertson DH, Gaskell SJ, Oliver SG, and Beynon RJ. Dynamics of protein turnover, a missing dimension in proteomics. Mol Cell Proteom 1: 579-591, 2002.

36. Rosenfeld J, Capdevielle J, Guillemot JC, and Ferrara P. In-gel digestion of proteins for internal sequence analysis after one- or twodimensional gel electrophoresis. Anal Biochem 203: 173-179, 1992.

37. Walsh MK and Brown RJ. Use of amino acid analysis for estimating the individual concentrations of proteins in mixtures. J Chromatogr A 891: 355-360, 2000.

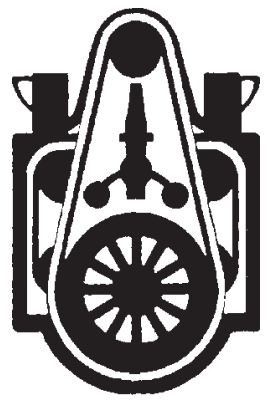


Volume 291, July 2006

Volume 54, July 2006

Pages E190-E197: Abdul Jaleel, Vandana Nehra, Xuan-Mai T. Persson, Yves Boirie, Maureen Bigelow, and K. Sreekumaran Nair. In vivo measurement of synthesis rate of multiple plasma proteins in humans.

In the above paper, under GRANTS on p. E196, it should have been written that the study was supported by grants from National Institutes of Health (R21/R33-DK-70179, R01-DK-41973, and M01-RR-00585) and the Mayo Foundation.

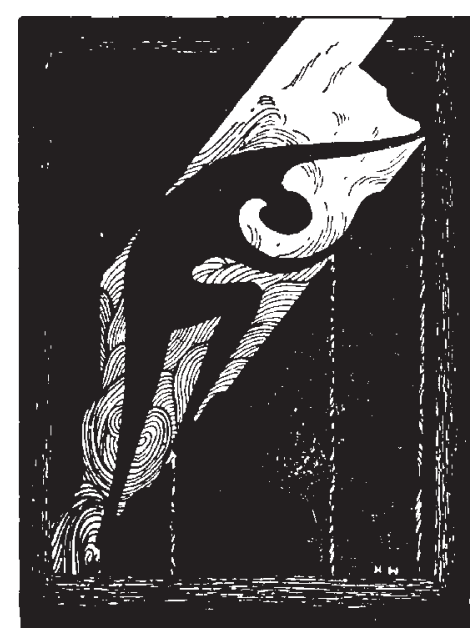

